\title{
Theoriestreit um das Verhältnis von Zins- und Wachstumsrate
}

Seit dem Ausbruch der Wirtschafts- und Finanzkrise wird die lang anhaltende Niedrigzinsphase zunehmend kontrovers diskutiert. Dabei kommt dem Zusammenhang zwischen dem Zinssatz $r$ und der Wachstumsrate $g$ eine zentrale Rolle zu: So leiten einige Autoren bei $r<g$ eine Begründung für eine expansivere Fiskalpolitik ab. Diesem Thema widmen sich auch die Autoren Carl Christian von Weizsäcker und Hagen Krämer in ihrem aktuellen Buch „Sparen und Investieren im 21. Jahrhundert - Die große Divergenz“. Sie erörtern die Rolle der Determinanten des Zinses im Gleichgewicht aus Sparen und Investieren und leiten politische Implikationen ab. Die zentrale Grundthese ist, dass der negative Realzins ein Indikator dafür ist, dass zu viel gespart wird. Daraus ergibt sich die Forderung nach einer politischen Wende, weg von der Begrenzung der Staatsschulden, hin zu einer Reduktion des Sparüberschusses. Sowohl die Theorie als auch die Politikimplikation haben auf Fachkonferenzen ein breites Echo gefunden. Da diese Diskussionen im Streit der Denkschulen sehr lehrreich sind, sollen in diesem Zeitgespräch sowohl die Autoren als auch ihre Kritiker Hans-Werner Sinn, Peter Bofinger sowie Eckhard Hein zu Wort kommen, die jeweils ihre Sicht der Theorie und Evidenz zum Thema vorstellen.

Sparen und Investieren im 21. Jahrhundert: Das Ende der Kapitalknappheit Carl Christian von Weizsäcker, Universität zu Köln; Max-Planck-Institut zur Erforschung von Gemeinschaftsgütern, Bonn. Hagen Krämer, Hochschule Karlsruhe - Technik und Wirtschaft.

\section{Staatsverschuldung und dynamische Ineffizienz: Warum der Münchhausen-Trick} nicht funktioniert

Hans-Werner Sinn, ifo Institut für Wirtschaftsforschung; Ludwig-Maximilians-Universität München.

Sparen und Investieren im Spannungsfeld widerstreitender Paradigmen

Peter Bofinger, Universität Würzburg.

Sparen und Investieren im 21. Jahrhundert - die post-keynesianischer Perspektive Eckhard Hein, Hochschule für Wirtschaft und Recht, Berlin.

Title: Theoretical Dispute About the Relationship Between Interest and Growth Rates

Abstract: Since the outbreak of the economic and financial crisis, the prolonged phase of low interest rates has been increasingly controversial. The relationship between the interest rate $r$ and the growth rate $g$ plays a central role in this context: some authors derive a justification for a more expansionary fiscal policy at $r<g$. This topic is also addressed by authors Carl Christian von Weizsäcker and Hagen Krämer in their current book, "Sparen und Investieren im 21. Jahrhundert Die große Divergenz". They discuss the role of the determinants of interest rates in the equilibrium between savings and investments and derive policy implications. The central thesis is that the negative real interest rate is an indicator of excessive savings. This results in a call for political change, away from limiting public debt and towards a reduction of the savings surplus. Both the theory and the policy implication have elicited a great deal of attention at academic conferences. Since these debates are very instructive in the dispute between the schools of thought, this selection of essays will feature both the authors and their critics Hans-Werner Sinn, Eckhart Hein and Peter Bofinger, who will each present their views on the theory and the evidence of the topic. JEL Classification: E10, E43, E50 